\title{
Planning an Information Commons
}

Michael J. Whitchurch

Brigham Young University - Provo, michael_whitchurch@byu.edu

Follow this and additional works at: https://scholarsarchive.byu.edu/facpub

Part of the Library and Information Science Commons

\section{Original Publication Citation}

Journal of Library Administration, vol. 50, no. 1, pp. 39-50

\section{BYU ScholarsArchive Citation}

Whitchurch, Michael J., "Planning an Information Commons" (2010). Faculty Publications. 1547. https://scholarsarchive.byu.edu/facpub/1547 


\title{
Planning an Information Commons
}

\author{
Abstract \\ Of the steps in implementing an information commons, one of the most important is the planning \\ phase. In order for the planning and implementation to be a success, buy-in and support from library \\ users and administrators is essential. The result of the planning process is a detailed planning document \\ which will influence the success of the commons. The document should include plans for policy \\ changes, space for the commons, staffing issues, and assessments, both before and after \\ implementation. Even with all the planning completed, an evaluation of the viability of and desirability \\ for a commons should determine whether a commons should be implemented on each individual \\ campus.
}

\section{Keywords}

- Information Commons

- Planning

- Assessment

- $\quad$ Staffing

- Library

\section{Introduction}

Since the early 1990s and the birth of the World Wide Web, libraries have attempted to improve access to, creation of and dissemination of information. In addition, the pedagogy at institutions of higher education has moved more from one of individual learning to one of group learning. In recent years, classroom pedagogy has, largely because of student influence, focused more on collaboration and group projects rather than individual work. When referring to this "discontinuity with [the] past", Scott Bennett and the Council on Library and Information Resources (2003, p. 3) called this a fundamental change to "active learning practices." Bennett and the Council on Library and Information Resources 
further states that "[s]tudents everywhere were increasingly working in collaborative study groups of their own making, to engage more strongly and often more adventurously with their coursework" (p. 3). Some of the active learning practices being implemented in campus courses that promote this student desired collaboration include "problem-based learning, small-group work, study teams, and synchronous and asynchronous online communities of practice."(Johnson \& Lomas, 2005, p. 25)

Encouraged by this transition, libraries began to implement services that would facilitate and assist campus faculty and students with this change. To support the changes in information access and student study habits, some academic libraries created information commons (also called learning commons or knowledge commons), usually in reference areas of the library. These commons are flexible learning spaces, most often located in libraries, dedicated to the research, creation and dissemination of information. To become a "true information commons ... users must have all of the tools necessary to create knowledge." (Cowgill, Beam, \& Wess, 2001, p. 433) Often a commons will provide space for individual and group work, with or without a computer. Many also provide technology enabled group study rooms (Simmons College), presentation practice rooms (The Hong Kong University of Science and Technology), multimedia labs (Brigham Young University), or other university or college services such as Advisement and Transition at SUNY Cortland, or the Writing Help Center at Buffalo State College. These types of technologies and cooperation or collaboration require close relationships between the library and the campus information technology group. This is a key to the success of a commons.

The information commons concept was a solution to implementing services and resources in this new collaborative environment. Initially these commons were physical spaces devoted to using computers for information discovery and creation. As changes continued in academia, information commons expanded and began to implement more learning-centered technologies and services. Many commons 
still struggle to implement these learning-focused components in an effort to provide the best possible service for the users of the commons. Allison Cowgill [2001] summarizes what an information commons should accomplish: "The information commons incorporates changes in user needs and expectations by creating an environment that wholly supports the whole research process from beginning to end." (Cowgill et al., 2001, p. 433) This requires a high level of flexibility in the physical space as well as in the people who support the space.

\section{The Information Commons}

In his pivotal paper, "Conceptualizing an Information Commons", Donald Beagle [1999] describes two definitions, or what he calls levels, of the term information commons. Firstly, it is "used to denote an exclusively online environment in which the widest possible variety of digital services can be accessed via a single graphical user interface (GUI) and potentially searched in parallel via a single search engine from any networked workstation."(Beagle, 1999, p. 82) In other words, a metasearch of a variety of catalogs, databases and services. Secondly, "the phrase Information Commons has also been used to denote a new type of physical facility specifically designed to organize workspace and service delivery around the integrated digital environment described above."(Beagle, 1999, p. 82) Later, in a Public Policy Report, Nancy Kranich [2004] described the information commons as the open and cooperative sharing of information, particularly online. Much in the same way that an agricultural commons is open and cooperatively shared, so should information be openly shared. For a much greater discussion, the aforementioned public policy report is recommended (Kranich, 2004).

The information commons, as physical space, combines technology, service and atmosphere to create a dynamic, comfortable, and collaborative, yet educational, environment. To accomplish this, it needs to be flexible and adaptable. Pedagogy and student study patterns have changed at an accelerated pace over the last two decades. Simultaneously, the technology used to create and disseminate information 
has continued to change rapidly. "Given the rate of change in the design of computers and the production of electronic information, any library that incorporates technology into its reference space will need to plan for almost annual expansion."(Thomas, 2000, p. 411) While annual expansion is often impractical, a plan for expansion should be included. The expansion mentioned is primarily an expansion of services and support for new technology, rather than an expansion of footprint. To accommodate these changes, library spaces have needed to adapt to stay relevant. Thus is born the information commons.

\section{Pre-planning}

The implementation of an information commons should be carefully considered. Because of financial, political or other reasons, an information commons implementation may not be ideal or practical for every institution. In the pre-planning phase, support for the commons needs to be obtained. Support should come from groups including library employees, library administrators, students, faculty and campus administrators. Once the decision has been made, continued support from all of these groups is vital as well.

In addition to getting student support and input, it is imperative that campus administrators support the effort to develop a commons. This task becomes easier when "both the library and university administration [agree] that a library is the focal point of the university's intellectual life."(Holmes-Wong, Afifi, Bahavar, \& Liu, 1997, p. 74) The plan for the commons should conform to the mission, vision and values of the university. This will bring buy-in from campus administrators.

Before beginning the intense planning phase of an information commons, a local needs assessment should be completed. This assessment will not only inform the decision of whether a commons should be implemented, but will also help guide the planning process and implementation. The result of the 
assessment and subsequent evaluations will be used to determine the necessity and viability of creating a commons.

The needs assessment could be as simple as listening to users' wants (complaints) or the assessment could escalate to a complete assessment of the library. The University of Rochester study, Studying Students: the Undergraduate Research Project at the University of Rochester, is an excellent example of a complete anthropological study of the library. (Foster \& Gibbons, 2007) This study addressed issues regarding campus faculty, students and librarians as well as library facilities, schedules, collections, etc. While it is highly recommended to review this study and use the results to help inform decisions, assessment should be done at each individual institution, as every institution is unique. The ARL Learning Space Pre-Programming Tool Kit (Stuart, 2008) is also an excellent resource for any group wanting to investigate and study the feasibility of an information commons.

A needs assessment can be completed using many of the same evaluation/assessment methods that should continue to be used after implementation. Some of these methods are surveys and comments, focus groups, student and faculty advisory groups or survey tours, to name only a few. (Stuart, 2008) After evaluating the needs assessment, the services and space requirements for the commons should become evident. Each component or service suggested by the needs assessment should be considered equally and be evaluated for feasibility and desirability, based on the goals and mission of the library and the university.

\section{The Team}

Pre-assessment and planning should be managed by a small team or group. It should be comprised of personnel capable of conducting and evaluating the needs assessment, and of proposing an implementation plan. Each team member must understand the results of the needs assessment within the context of the university and library mission and vision. With this understanding, decisions will be 
made with patrons and services for them in mind. Providing a space that is useful and usable by the constituency should be the central desire guiding the team. The group should include representatives of those who have a stake in the outcome of the commons. The group's composition will be different for each library and will depend on the political climate, campus hierarchy and the scope of the information commons (i.e. room remodel or new building construction).

As a part of the investigation into a commons, not only should its viability be ascertained, but also what components and services the commons should contain. Some of the possible components of commons include: group study spaces, study rooms, multimedia stations or lab, café, personal assistance, and printing/copying capabilities. because the space should be customized to the needs of the particular community, no two commons are identical: each implementation of a commons is different from all the others.

As the team investigates components to include in the commons plan, it is worth the time and effort to investigate what other institutions have done in their planning process. Consult documents such as the “Information Commons: Planning Checklist," written by Susan Beatty and Hester Mountifield (2006, Appendix A), for guidance in planning. Studying the results of implementations and studies conducted at other institutions, along with site visits, when possible, is an important way to keep from reinventing the wheel. However, this caution from Georgia Tech should be kept in mind, "the most effective learning spaces complement and respond to one's own faculty and students. Rather than mimicking what others have done, you must perform your own user-centered discovery." (Fox \& Stuart, 2009)

\section{The Planning Document}

The planning document is the most important product of the planning team. This document will largely determine the success of the information commons implementation. It is for this reason that, when possible, planning documents should be obtained from other institutions which have successfully 
implemented a commons. Looking to the experiences of others will help facilitate brainstorming as well as the overall document creation process.

Build phasing into the process. Change will continue to occur in the technology and in the group that the commons serves. A great example of phasing in an information commons can be found at Georgia Tech. Their process started with the renovation of just a part of their library in 2001. Phase two was completed in 2006 and the third phase is currently in process. Through each of the first two phases lessons were learned that are being applied to the current phase.

Of the conveniences that can be provided to students in the commons, one of the most helpful is to create a one-stop-shop of services. The fewer points of service available, the happier the student will be when leaving the library. Traditionally library services have been very siloed, working independently from one another. However, in many institutions, as reference statistics are in a downward trend and given the depressed financial situation many institutions are experiencing, combining various public services should be considered. Possible inclusions in such a meta-service could be circulation, reserve, reference (knowledge discovery systems), and media services. In addition to library services, other campus services such as the writing center, tutoring, etc., should be considered for inclusion into the one-stop-shop commons.

\section{Spaces}

It is important to carefully consider the space the commons will occupy. If a new library building is being constructed, a commons needs to be considered in the planning of that building (e.g. Utah State University, University of Southern California). In cases where a commons will be implemented in an existing building (e.g. University of Utah, University of North Carolina-Charlotte), the space needs to be large enough to provide for all of the desired services. In addition, a plan for scaling or phasing needs to 
be in place. If the new building will be dedicated to the information commons (e.g. Loyola UniversityChicago, University of Sheffield) the planning process will be much different.

When information commons are discussed most people think of them as being located in a library. However, these spaces "might conceivably be located elsewhere-in, for instance, a student center." (Bennett, 2003, p. 39) Because libraries provide much of the essence of information retrieval, creation and dissemination they make ideal locations for information commons. However, adequate services may be implemented elsewhere.

Academic libraries have traditionally been quiet spaces for study and contemplation, but that has changed. The students who frequent the library are using the space for more group work. Because of this and the change in class pedagogy, collaboration has become an integral part of a contemporary college. With the advent of online social networks, online collaboration is the most widely used form, but in-person collaboration remains important for social development.(Beatty \& Mountifield, 2006, p. 236) Information commons should be comfortable and adaptable to the needs of the user. For example, individuals who prefer to study where there is a constant hum of activity often use these group spaces.

Despite the need for group spaces in a library, it is still essential to have some spaces set aside elsewhere in the library for individual quiet study. "Be creative with . . . technology-free environments" (Beatty \& Mountifield, 2006, p. 235) which are spaces not only free of talking, but also free of the quiet hum of computers or the ringing cell phones. Areas with little or no cell phone reception should be considered for this type of space. This speaks to the flexibility and adaptability of the library in meeting the needs of users with a variety of personalities and study styles. Be sure to provide space for as many as possible. Ask the users which spaces are most important. 
When discussing the information commons space, consider allotting space for other campus entities. The library should be viewed as the center of the campus community. One of the best ways to support this notion is to invite campus collaborators into the commons. Possible campus collaborations include the writing lab, tutoring, or academic advising, among others. These entities should be treated as partners in the commons development and invited into the discussions. If they are involved from the beginning they will feel a shared ownership in the space and perceive that they also have a stake in its success.

Even with a well planned and implemented commons, some things will not turn out as planned. "Often, it is not until a space is pushed to its limits that the desirable (or lacking) features can be identified." (Johnson \& Lomas, 2005, p. 26) Allow the users to innovate in the space and allow for a highly reactive development as well as a planned one. Items that allow for this creativity include furniture on wheels, mobile accessories (white boards, reconfigurable walls, etc.) and opportunities to experiment with new possible developments (sandbox). The commons needs to support "the creativity, experimentation and playfulness of the users [which] can uncover potential new uses." (Johnson \& Lomas, 2005, p. 26)

Information commons have largely been developed with undergraduates in mind. While this is laudable, and perhaps preferred, graduate students and faculty should be considered in developing library space because their needs are typically different from the needs of undergraduates. A space set aside for, and marketed to, graduate students and faculty should be considered if they do not feel comfortable in, or their needs are not being met by the existing commons space.

It is hard to discuss library spaces without mentioning the use of the virtual space. Virtual commons encourage collaborative relationships in the development of class work or group projects. Virtual commons have not been adequately explored yet, but with the reliance of students on the online environment, they will become more used and useful to the student. The Georgia Institute of 
Technology has created a virtual design laboratory for students to vote on emerging concepts and provide narrative feedback.

To summarize, consider space types, service components, and the needs of all the library constituents. Build flexibility into the space with moveable furniture and a variety of services. Doing so will allow users to create personalized space.

\section{Assessment}

As a commons is planned and implemented, the need to "incorporate the means of measuring the effectiveness of the library design and evaluating the impacts of decisions made in the programming phase" (Thomas, 2000, p. 410) must be addressed. Post-implementation evaluation and assessment is an ongoing process that will continue to inform decisions regarding improvements or phases in the process. Results of such assessments frequently bring to light "new and important questions, which can then be integrated into the [iterative] design process."(Thomas, 2000, p. 410)

The "Space Planning Toolkit" developed by Crit Stuart for ARL (http://www.arl.org/bm doc/planning-alearning-space-tool-kit.pdf) contains examples of assessments that can be used to evaluate the implementation of a commons. Georgia Tech used many of the suggestions in the toolkit and in addition used their Library Student Advisory Council as a source for information and assistance in implementing the assessments. Observation was one "user-centered discovery techniques" used (Fox \& Stuart, 2009). Others user-centered discovery techniques include:

- "Organizing focus groups

- Conducting random interviews

- Observing where students go in the library when the East and West Commons are full

- Creating a virtual design laboratory

- Consulting findings from East Commons discovery and assessment activities

- Working with outside experts

- Involving the Library Student Advisory Council in user-centered discovery and interpretation of data 
- Mentioning the project frequently in campus media to generate user interest and participation

- Conducting design charrettes." (Fox \& Stuart, 2009)

These assessments will help find components that stakeholders or users of the space want to see implemented. Vetting ideas through these groups can happen through surveys, focus groups and a sandbox. Surveys facilitate the accrual of desirable outcomes, but do not provide the interpersonal interaction apparent in a conversation. Focus groups capture the spontaneity of conversation while discussing options for an information commons, but they require more time and money than surveys. A sandbox, or test space, is ideal for investigating furniture or other services that are tied to a space. Each of these, and others, can be important in assessing how service oriented an information commons really is.

To repeat, because the technology and learning environments change rapidly an assessment plan needs to be in place when the commons opens. This will ensure that any changes will be done with the right motivations and will improve the chance of achieving their desired ends. Creating an initial assessment plan should be part of the charge for the investigation and planning team.

\section{Policies}

Clear policies and guidelines need to be in place so the students know what options exist in the space and the rules for using it. Policies regarding noise, computer usage (in the case of a technology-free zone), cell phone use and group space should be clearly defined and adequately displayed throughout the library. Many libraries have modified their policies to allow food in the commons space, or throughout the library. This response to the user's request has become a great success in many libraries. The By George café at the Odegaard Undergraduate Library at the University of Washington is just one example. It was implemented in a library space near the entrance that had become less important for library work and study. This is an example of how libraries are responsive to students and the way they want to use the library. 


\section{Other Resources}

The current generation of college students is a connected generation. They expect to be connected wherever they may be. Although wired connections seem less necessary currently, some students still need a wired connection. These connections should be considered and placed where the students will use them. The commons will be even more service oriented by making Ethernet cables available for purchase or check-out.

Most libraries are transitioning their reference collections from print to electronic formats. While developing a plan for an information commons, address those reference services that are either not available online, have not been purchased for online access, or are preferred in print by some patrons. These items should be considered for inclusion in the information commons. Such decisions should be based on assessments, and any resulting collection should match the assessed needs of the users.

\section{Staffing}

Staffing the commons will depend largely on the services that are provided in the space. Most commons implementations provide at least basic computer support and reference services. Another aspect of staffing is management. Should the manager be a librarian, or a support staff person? Regardless of the answer, the manager must understand the capability of all the technology that is supported by the commons. This does not mean that the manager should know how to do everything, but that that the manager knows what the technology is there for. A deep understanding of the purpose or mission of the commons is essential in providing the best service possible. This includes understanding other services that may share the commons space, such as a writing center satellite, publication lab, or academic advising, but which will not necessarily be supported by the commons staff.

Another essential aspect of staffing is the training program that is implemented for commons staff. Again, depending on the services provided in the commons, the training needs to be pertinent. Perhaps the most difficult aspect of training staff to work in an information commons is the rapid pace of change 
in technology. "Training must keep pace with technology changes and system upgrades. Adequate training can involve a great deal of time and money, which are often in short supply" in many libraries. (MacWhinnie, 2003, p. 244) Inadequate training can result in inferior service and loss of good will toward the library. In addition to training on the technology available in the commons, continuous training and practice in customer service skills is necessary.

Finally, a decision will need to be made regarding the composition of the team working in the public space (on a desk or otherwise). What mix of students, support staff and/or librarians will there be in the commons? What level of expertise will be expected of each staff level? Some patrons tend to more easily approach student workers than support staff or librarians. On the other hand, other patrons view support staff or librarians as the most knowledgeable and gravitate to them.

\section{Conclusion}

Information commons truly have had an impact on the use of academic libraries. Gate counts have increased and the general view of the library has improved. "The Information Commons in libraries has demonstrated that college students will come to the library if there is something there that they need."(Simon, 2006, p. 9) The information commons is a response to the increased availability of information and the need students have for space dedicated to information discovery, sharing (in a group setting) and creation.

A successful commons continually assesses and adapts. "The future of the academic library will continue to be molded by user demands and driven by technological advances."(MacWhinnie, 2003, p. 254) Ask the users what they need and want and then adapt to those needs within the scope of the library and university mission and vision. Success will be evident when "Information commons support the important relationship between information technology and academic scholarship by providing 
areas in libraries that provide a full-range of library resources and productivity software."(Cowgill et al., 2001, p. 438)

The success of an information commons depends upon the planning process. Support from all stakeholders is vital, as is a mindset of innovation and flexibility. Pre-planning assessment should inform the planning document provided by the investigation team. That document should be concise while also being specific about services, staffing, and ongoing assessment. It should provide for the option of phased implementation, if necessary.

The information commons is more than just a space or an idea, it is an ideal toward which we should all work. The ideal is the unobstructed access to existing and the creation of new information in ways that respond and support the learning environment of higher education today.

\section{References}

Beagle, D. (1999). Conceptualizing an information commons. The Journal of Academic Librarianship, 25(2), 82-89.

Beatty, S., \& Mountifield, H. (2006). Collaboration in an information commons: Key elements for successful support of e-literacy. ITALICS: Innovation in Teaching and Learning in Information and Computer Sciences, 5(4), 229-245.

Bennett, S., \& Council on Library and Information Resources (2003). Libraries designed for learning. Washington, D.C: Council on Library and Information Resources.

Cowgill, A., Beam, J., \& Wess, L. (2001). Implementing an information commons in a university library. Journal of Academic Librarianship, 27(6), 432-439. 
Foster, N. F., \& Gibbons, S. (2007). Studying students: The undergraduate research project at the university of rochester. Retrieved 05/06, 2009, from http://docushare.lib.rochester.edu/docushare/dsweb/View/Collection-4436

Fox, R., \& Stuart, C. (2009). Creating learning spaces through collaboration: How one library refined its approach. Retrieved 1, 32, from http://www.educause.edu/EQ/EDUCAUSEQuarterlyMagazineVolum/CreatingLearningSpac esThroughC/163850

Holmes-Wong, D., Afifi, M., Bahavar, S., \& Liu, X. (1997). If you build it, they will come: Spaces, values, and services in the digital era. Library Administration \& Management, 11(2), 74-85.

Johnson, C., \& Lomas, C. (2005). Design of the learning space: Learning and design principles. Educause Review, 40(4), 16-28.

Kranich, N. (2004). The information commons: A public policy report. Retrieved 10/07, 2008, from http://www.fepproject.org/policyreports/InformationCommons.pdf

MacWhinnie, L. A. (2003). The information commons: The academic library of the future. Portal: Libraries \& the Academy, 3(2), 241-257.

Simon, M. (2006). Beyond computers: The impact of the information commons on library design in academic institutions. LACUNY Conference Keynote, May 18, 2006, Baruch College of the City University of New York. 
Stuart, C. (2008). ARL learning space pre-programming tool kit. Association of Research Libraries. Retrieved from http://www.arl.org/bm doc/planning-a-learning-space-tool-kit.pdf

Thomas, M. A. (2000). Redefining library space: Managing the co-existence of books, computers, and readers. The Journal of Academic Librarianship, 26(6), 408-415. 